\title{
Precision overhead irrigation is suitable for several Central Valley crops
}

by Jeffrey P. Mitchell, Anil Shrestha, Joy Hollingsworth, Daniel Munk, Kurt J. Hembree and Tom A. Turini

\begin{abstract}
Overhead systems are the dominant irrigation technology in many parts of the world, but they are not widely used in California even though they have higher water application efficiency than furrow irrigation systems and lower labor requirements than drip systems. With water and labor perennial concerns in California, the suitability of overhead systems merits consideration. From 2008 through 2013, in studies near Five Points, California, we evaluated overhead irrigation for wheat, corn, cotton, tomato, onion and broccoli as an alternative to furrow and drip irrigation. With the exception of tomato, equal or increased yields were achieved with overhead irrigation. Many variables are involved in the choice of an irrigation system, but our results suggest that, with more research to support best management practices, overhead irrigation may be useful to a wider set of California farmers than currently use it.
\end{abstract}

\begin{abstract}
A 1976 Scientific American article called center-pivot irrigation "perhaps the most significant mechanical innovation in agriculture since the replacement of draft animals by the tractor" (Splinter 1976). Patented in 1952 by Frank Zybach, a farmer in eastern Colorado, center-pivot systems are automated, precision irrigation water application machines typically made up of seven or eight connected pipes with drop hoses and sprinkler nozzles that rotate in a line around a pivot point. Linear move systems are similar but apply irrigation water in a straight
\end{abstract}

line across a field. Together, center-pivot and linear move systems are known as overhead, or mechanized, irrigation systems and are the most prevalent form of irrigation system in the United States (NASS 2013). They account for the irrigation of $50.4 \%$ of total U.S. irrigated acreage.

In Nebraska, the state with the highest crop acreage under irrigation, 70,000 overhead systems are used on more than 7.2 million acres $-87 \%$ of the state's total irrigated land - and the remaining gravity irrigation systems are being rapidly replaced by overhead systems because of overhead systems' superior application precision and yield benefits (Pfeifer and Line 2009). In California, by contrast, roughly 350 overhead systems irrigate about 150,000 acres, just $2 \%$ of the state's total irrigated acreage.

\section{Technology adoption}

Several factors may have contributed to the slow rate of adoption of overhead irrigation in California.

First, difficulties encountered by early adopters of the technology led to overhead systems gaining an undeserved reputation for being unable to keep up with California's high crop evapotranspiration demands, losing unacceptably large amounts of water to evaporation, and being prone to getting stuck in muddy fields. While successful installations of center-pivot systems in recent years show that the technology can in fact work well in California, these negative perceptions persist.

Incomplete coverage by center-pivot systems is another issue. With a standard center-pivot system, roughly $20 \%$, or 33 acres, of a typical 160-acre (quarter section) field is unirrigated. "Swing-out"

Online: http://dx.doi.org/10.3733/ca.v070n02p62
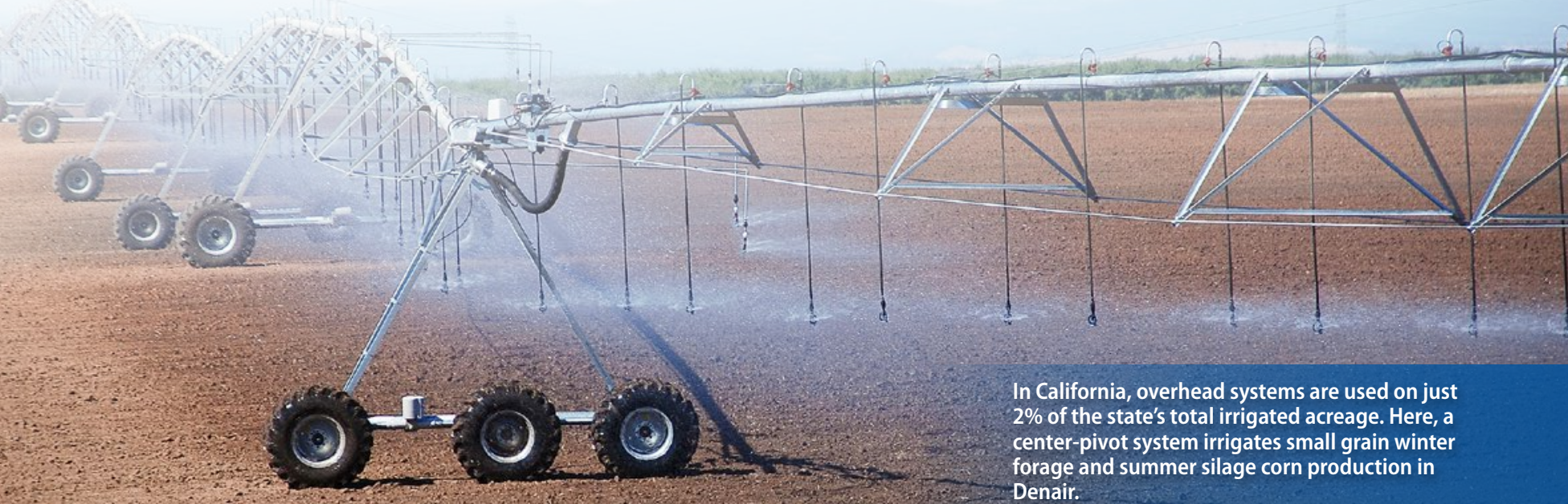

In California, overhead systems are used on just $2 \%$ of the state's total irrigated acreage. Here, a center-pivot system irrigates small grain winter forage and summer silage corn production in Denair. 
extension arms - designed to irrigate the corners of a square field - and the practice of "close-packing" irrigation circles in a hexagonal array can help to address this issue, but both have drawbacks. Swingout systems are expensive, adding $\$ 25,000$ to $\$ 45,000$ to the cost of center-pivot system depending on options. As a result, they tend to be used mainly on high-value crops such as potatoes. The hexagonal-array approach was introduced in the 1960s but hasn't been widely adopted because land tends to be divided up into regular square and rectangular parcels (Ganzel 2006).

The work of UC ANR Cooperative Extension (UCCE) on drip irrigation since it was introduced in 1969 brings the state an estimated $\$ 78$ to $\$ 283$ million annually in water savings and yield increases (Taylor et al. 2014). There has been far less research on overhead irrigation systems in California, despite their earlier introduction in the state. In the 69-year history of this journal, for instance, only three articles address overhead irrigation (Hanson and Orloff 1996; Hanson et al. 1986; Smith et al. 1991).

The dramatic expansion of drip irrigation in California over the past 30 years may provide a parallel to what is currently happening with overhead irrigation. There was an initial reluctance toward believing that drip technology would ever have a role in crop fields that had for 50 years been surface irrigated. However, drip caught on through the bold and pioneering early work of applied researchers Don May, of UCCE Fresno County, and Claude Phene, of the USDA Agricultural Research Service's San Joaquin Valley Agricultural Water Management Laboratory, in Parlier. They identified optimal water management practices for high-yielding, drip-irrigated processing tomatoes, and growers became receptive to the technology. Now drip is used on $90 \%$ or more of San Joaquin Valley tomato acreage (Mitchell et al. 2014). Similarly, as research results demonstrate the benefits of overhead irrigation, the technology may spread.

The possibilities of overhead irrigation systems being useful choices for some crops in California agriculture deserve exploration. Overhead irrigation systems have been adopted in many regions of the world since the 1950s because they can irrigate large tracts of land automatically,

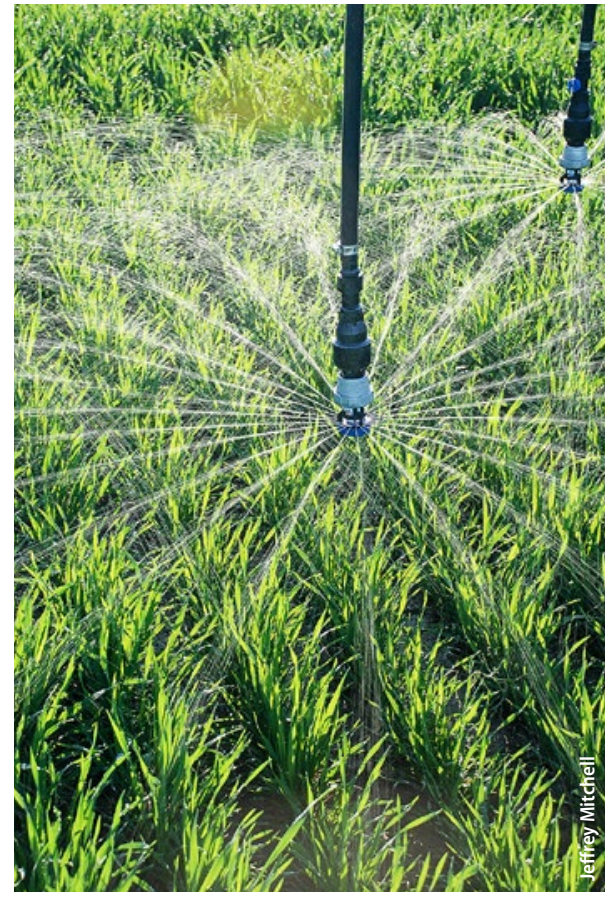

A wheat crop is irrigated in Five Points with a low-elevation spray application system, which has applicators positioned 12 to 18 inches above the ground.

lightly and frequently; can inject fertilizers and herbicides directly into the water supply line; and can accommodate rolling terrain and coarse or sandy soils (Splinter 1976). Overhead irrigation also has a distinct advantage over other irrigation methods in its labor requirements. Overhead systems require less maintenance than drip systems in terms of avoiding clogging of emitters and repairing leaks. In addition, overhead irrigation may also aid salinity management by uniformly leaching salts from a crop's root zone (John Diener, farmer, Five Points, personal communication).

On October 2, 2010, about 30 university and private sector partners (including author Mitchell) established the California Overhead Irrigation Alliance (COIA) to develop and provide research-based information on overhead irrigation systems. Since its inception, COIA has conducted a variety of studies, provided several public field days and farm tours related to overhead irrigation, and has been involved with a number of overhead irrigation demonstrations for various crops grown in the Central Valley. COIA did not fund the work reported in this paper.

\section{Selecting an irrigation system}

Selecting and purchasing an irrigation system is expensive and complex

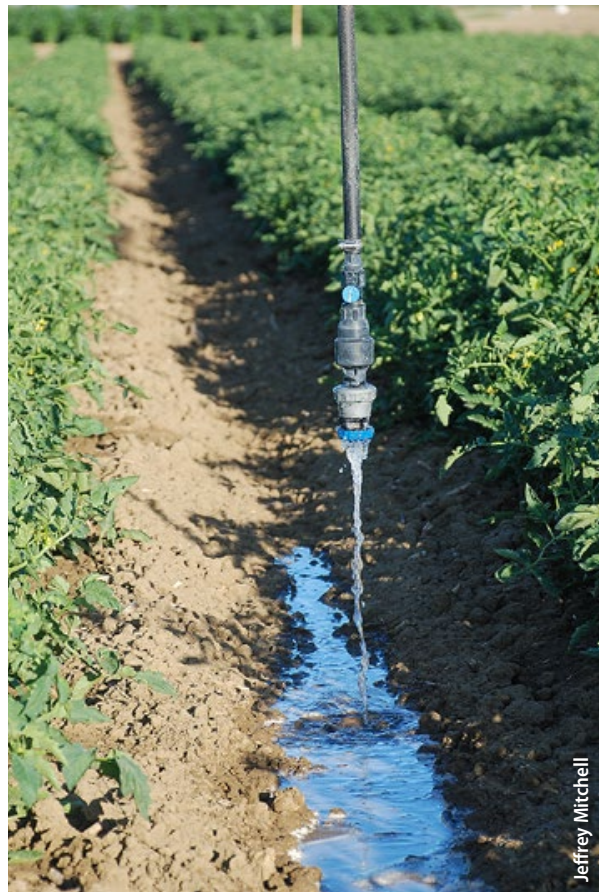

Researchers used bubbler nozzles, above, on the tomato crop from transplant establishment through the early vegetative growth phase to minimize soil evaporation.

(Amosson et al. 2011). The decision involves a number of factors, including available financing, crop rotation, energy prices, energy sources, application efficiency, operating pressure and the depth from which water must be pumped. A recently published study provides a number of relevant considerations to assist growers in making decisions about irrigation systems by detailing the costs and benefits of five types of commonly used irrigation systems. These include furrow, or surface, irrigation; subsurface drip irrigation (SDI); and three types of center-pivot systems: mid-elevation spray application (MESA) systems that have water sprayer heads positioned about midway between the mainline and ground surface; low-elevation spray application (LESA) systems that have water applicators positioned about 12 to 18 inches above ground level; and low energy precision application (LEPA) that apply water with drop socks or bubblers near the ground surface (Amosson et al. 2011).

An irrigation system's operating pressure, first of all, affects the cost of pumping water. Higher pressure makes irrigation more expensive (table 1). Furrow systems typically require the lowest operating pressure. LESA, LEPA and SDI have similar operating pressures. The percentage of irrigation water used by the 
crop relative to the total amount of water applied, the application efficiency, also varies between irrigation systems, with furrow systems typically having lower efficiencies (table 1). Higher application efficiency reduces the amount of water used, which in turn affects operating costs (Amosson et al. 2011).

The investment costs for irrigation systems also vary considerably, from about $\$ 210$ per acre for furrow and \$556 per acre for a quarter-section center-pivot system, to $\$ 1,200$ per acre for an SDI installation in 2011 dollar values (Amosson et al. 2011).

The cost advantage for a center-pivot system over an SDI system, however, may diminish as field size is reduced below a quarter section of land ( $\mathrm{O}^{\prime}$ Brien et al. 1998). In addition, system cost comparisons are sensitive to the assumed life span of the system. Center pivots tend to last longer than SDI systems, meaning that the capital costs can be spread over a longer period (O’Brien et al. 1998).

Technical support services to support conversion to overhead systems are increasingly available in California, with all four major companies having a significant presence in the state (Rick Hanshew, Reinke Mfg.; Dan Schueler, Senninger Co.; Chuck Powell, Lindsay Zimmatic Co.; Jerry Rossiter, T \& L Irrigation Co.; John Bliss and Pat Murray, Valmont Industries; Craig Stafford, Nelson Irrigation, personal communication).

The potential advantages of overhead systems, however, need to be balanced with the higher rates of water application and soil water evaporation compared with SDI. Also, overhead water application rates must be carefully matched with a soil's intrinsic water intake rate, to avoid runoff and lower application uniformities. In sum, farmers must keep many factors in mind and carefully weigh trade-offs.

\section{Irrigation systems study}

Since 2008, at the UC West Side Research and Extension Center, in Five Points, we have been conducting a variety of large-scale comparisons of overhead irrigation for crops common to the Central Valley. The purpose of these evaluations has been (1) to determine whether yields can be achieved with overhead irrigation that are comparable to yields achieved with furrow and drip irrigation for wheat, corn, cotton, tomato, onion and broccoli; (2) to develop best management practices

TABLE 1. Typical characteristics of five irrigation distribution systems

\begin{tabular}{lcccc}
\hline \hline & $\begin{array}{c}\text { Operating } \\
\text { pressure* }\end{array}$ & $\begin{array}{c}\text { Application } \\
\text { efficiency }\end{array}$ & $\begin{array}{c}\text { Efficiency } \\
\text { index } \neq\end{array}$ & $\begin{array}{c}\text { Gross } \\
\text { investment }\end{array}$ \\
\hline Furrow & $p s i$ & $\%$ & & $\$ / a c$ \\
Mid-elevation spray application (MESA) & 10 & 60 & 1.47 & 208.56 \\
Low-elevation spray application (LESA) & 15 & 78 & 1.13 & 556.00 \\
Low-energy precision application (LEPA) & 15 & 95 & 1.00 & 0.93 \\
Subsurface drip irrigation (SDI) & 15 & 97 & 0.92 & $1,200.00$ \\
\hline
\end{tabular}

Source: Adapted from Amosson et al. 2011 with permission.

* $\mathrm{psi}=$ pounds of pressure per square inch of water.

$\dagger$ Application efficiency = percentage of irrigation water used by a crop relative to the amount applied.

‡ Efficiency index = amount of water (inches per acre) that each system would have to additionally apply to be as effective as the LESA system.

for overhead irrigation that can be used to increase the performance of this technology in California; and (3) to synthesize recent farmer experiences with overhead irrigation for a variety of crops in California.

The crops studied are currently irrigated using a variety of systems. Corn and wheat are customarily furrow irrigated. Cotton is generally furrow irrigated as well, but in recent years is increasingly irrigated with either surface or SDI. Onions and broccoli are typically irrigated by sprinklers, but also in some cases, by surface or SDI. Tomatoes, as mentioned above, are predominantly irrigated by SDI. Performance data for some of the crops in our study have been recently published elsewhere (Hollingsworth et al. 2014; Mitchell et al. 2014; Mitchell, Carter et al. 2015); here, we summarize our evaluations of overhead irrigation.

Field plots. Field studies were conducted from 2008 through 2013 in two adjacent 3.24-hectare (8-acre) fields at UC West Side Research and Extension Center, in Five Points (N 36 20'14", W 120 6 6 $58^{\prime \prime}$ ). The soil type was a Panoche clay loam (fine-loamy, mixed, superactive, thermic Typic Haplocambids) with a $0 \%$ to $2 \%$ slope.

The experimental design for wheat and corn was a split plot with three replications. Irrigation system (furrow or overhead in 2008-2009 and 2009-2010, and SDI or overhead in 2012-2013) was the main plot and tillage (standard or notill) was the subplot. Overhead irrigation complements no-till and other conservation agriculture practices by minimizing soil disturbance. In each year, all plots of wheat and corn were established using the overhead system.
For cotton, onions, tomatoes and broccoli, the experimental design was a randomized complete block with four replications where treatment comparisons included two irrigation systems (overhead and surface drip for onions, overhead and SDI for the other crops). All crops were initially established using the overhead system. The tomatoes were transplanted using a three-row finger transplanter (Mitchell et al. 2014).

Crop varieties. Varieties of crops included the Dekalb corn hybrid DKC6788 (Monsanto Co., St. Louis, Missouri), the general-purpose hard red spring forage wheat variety WB Patron (Monsanto Co., St. Louis, Missouri) and the broccoli hybrid Green Magic (Park Seed, Hodges, South Carolina).

Overhead irrigation system. The overhead irrigation was a Valley lateral move system (Valmont Industries, Valley, Nebraska), with eight 150-foot-wide (46.1-meter) spans. The area under each span was considered a treatment plot. Thus, each treatment plot was 150 feet wide by 300 feet long. The system was fitted with spinner-type nozzles that spin 360 degrees (outer nozzles had a 180-degree center-facing range to prevent overlap with adjacent plots). Nozzles were spaced 5 feet (1.52 meters) apart and 3 feet (0.91 meter) off the ground.

SDI system. In alternate spans, the nozzles were turned off and $7 / 8$-inch(2.25-centimeter-) diameter Netafim Streamline 875 0135F drip tape (Netafim USA, Fresno, California) was installed 12 inches (30 centimeters) deep in the soil and 30 inches (76 centimeters) apart. In each row, the emitters were spaced every 13.8 inches ( 35 centimeters). The drip tape was maintained in the plots for the entire course of the study. 
Fertilizers. Cultural practices that are common in this region were used for all crops. Fertilizer nitrogen (N) was applied in all plots at 150 pounds per acre for wheat and 200 pounds per acre for corn exclusively via fertigation for the overhead systems and a combination of ground-applied and water run for the furrow irrigation systems. Fertigation applications of UAN32 totalling 269 pounds per acre for onion, 185 pounds per acre for cotton, 180 pounds per acre for tomato and 245 pounds per acre for broccoli were made to both the overhead and SDI systems.

Growth analysis, harvest. In these studies, we used the functional approach to crop growth analysis (Hunt 1982): We evaluated the change in crop biomass by sampling whole plants at weekly intervals to gain a more detailed season-long assessment of crop growth in the experimental treatments - taking, drying and weighing destructive biomass harvests of the wheat, corn, onion and tomato, and measuring the canopy coverage with a digital IR camera (Dycam ADC Camera, Woodland Hills, California) of tomato and broccoli (Mitchell et al. 2014). Crops were harvested using commercial mechanical harvesters or a farmer-supplied hand-harvest crew (broccoli), and yields were determined using gondola trailers and electronic scales mounted on trailers for all crops except broccoli. For broccoli, harvest bin trailers were weighed using drive-on commercial scales at a nearby farm.

Seeding issues, weeds. There were no observed insect or disease pest issues or other cultural anomalies that warranted unusual interventions. In the 2008 notill wheat plots, however, we did notice lower plant populations in the bottoms of residue-laden furrows due to difficulties the no-till grain drill had in seeding and in placing seed in good contact with soil. Also, heavy weed pressure was observed in all the plots and required frequent hand-weeding in the two onion studies.

Yields. Yields were determined by machine harvesting and weighing the aboveground wheat biomass in 2008 to 2010 and the grain in 2012, and by combine harvesting and weighing the corn. Data were analyzed using SAS v. 9.2 (SAS Institute, Cary, North Carolina). Testing for normality and homogeneity of variance checked assumptions of ANOVA.
Water applications. Irrigation events were scheduled and applied based on accumulated daily evapotranspiration $\left(\mathrm{ET}_{\mathrm{o}}\right)$ data from the CIMIS (California Irrigation Management Information System) station 100 yards from the study site and crop coefficient $\left(\mathrm{K}_{\mathrm{c}}\right)$ values based on percentage canopy cover estimates (Grattan et al. 1998; Hanson and May 2006). We assumed the same $K_{c}$ values for each irrigation system. Additional work is needed, however, to determine how crop ET and $\mathrm{K}_{\mathrm{c}}$ values differ with different irrigation systems. Total water applications were verified through in-line flowmeters and were kept as similar as possible for each irrigation system.

Cost estimates. Economic budget data were obtained from published UCCE production cost studies (Stoddard et al. 2006; Takele et al. 2013; Tourte and Smith 2010; Wilson et al. 2011) and also from surveys of five Central Valley farmers. Costs associated with installing and removing sprinkler pipe for crop germination and establishment and for installing and removing thin-walled (6 to $8 \mathrm{mil}$ ) surface drip tape were estimated. These costs would be required when rotating from a subsurface-irrigated crop such as tomato to a common Central Valley rotation crop such as onion or garlic, for which surface or near-surface (2 to 3 inches below the soil surface) tape is used.

Application uniformity. The Christiansen coefficient of uniformity (CU) was determined using the equation below for the overhead irrigation system using catch cans (Mitchell, Shrestha et al. 2015):

$$
C U=100[1-(A / B)]
$$

where $\mathrm{CU}$ is the Christiansen coefficient, $A$ is the sum of the absolute value of the deviation of the average catch can value from each individual catch can data point and $B$ is the sum of the catch can observations. The $\mathrm{CU}$ is the easiest and most widely used method for determining application uniformity of overhead systems (Harrison and Perry 2013).

Uniformity of the furrow and SDI systems was not determined in these studies and was not used in the scheduling of irrigations for any of the systems. Because of the short irrigation runs of the experimental fields (300 feet), we may reasonably assume that the efficiencies of the furrow and drip systems were in the high range of reported values $(60 \%$ to $85 \%$ for furrow, and 97\% for SDI) (Amosson et al. 2011; Hanson et al. 1997; Hanson et al. 1999).

\section{Irrigation systems performance}

With the exception of tomato, equal or increased yields were achieved with overhead irrigation relative to a variety of comparisons with furrow and drip (SDI except for onion plots, which were irrigated with surface drip) for wheat, corn, cotton, onion and broccoli. Similar water amounts were applied in the overhead system and the drip systems. More water was applied to the furrow systems than the overhead system due to the lower application efficiencies of the furrow system and to the inherent difficulty of achieving uniform water infiltration across a field with furrow irrigation, particularly following intensive intercrop tillage, which is routinely done to prepare beds for subsequent cropping.

Wheat. Similar amounts of water were applied in both the overhead and SDI systems for the 2012-2013 wheat grain crop. However, because of difficulties applying the initial furrow irrigations for germination of the shorter-season green chop wheat crops (wheat crop biomass harvested green or fresh for use as animal feed) in 2008-2009 and 2009-2010, about 8 inches more water were applied in the furrow systems than in the overhead systems (table 2); such initial furrow applications are common to "push" water across recently tilled fields.

The CU of the overhead system was determined to be $93.3 \%$, a very high level of water application evenness (Mitchell, Shrestha et al. 2015). Our overhead system was a linear move system, which has a higher inherent application efficiency than a pivot system, but the relatively high uniformity may also have resulted from improvements made in recent years with water application packages (nozzles and pressure regulators) (Dan Schueler, Senninger Co., personal communication).

Comparing green chop forage wheat production under furrow and overhead irrigation in 2008-2009 and 2009-2010, we found no effect of tillage in either year, and no irrigation system effect in the second year, but yields in the overhead system plots were lower than in the SDI plots in the first year (fig. 1). We speculate that the overhead system yields may have 
been lower in the first year because of the very high number of overhead irrigations applied (30, compared with 18 in the second year), which likely resulted in a higher proportion of applied water being lost as evaporation and less water stored in the soil compared with the second year (Mitchell et al. 2014; Thompson et al. 1997); also $\mathrm{ET}_{\mathrm{o}}$ was higher in the first year (table 2).

Evaporation from soil tends to proceed in two relatively distinct stages between soil wetting events. In the first stage, which is generally called energy-limited, or atmosphere-limited, evaporation is governed mainly by atmospheric conditions and the energy available to vaporize water in the near-surface soil atmosphere (Salvucci 1997). The second stage, generally termed soil-limited evaporation, is characterized by decreasing evaporation rates and is limited by water availability and diffusion in the soil. More first-stage evaporation occurred with the overhead system than the furrow system because of the much more frequent soil wetting with the overhead system; the furrow system had more second-stage evaporation.

Aboveground forage biomass accumulation measured during the second season by sampling 1-square-meter plots within each replication showed no consistent trends for either the tillage or irrigation systems (fig. 2). A goal of the functional approach to crop growth and development sampling is to take frequent

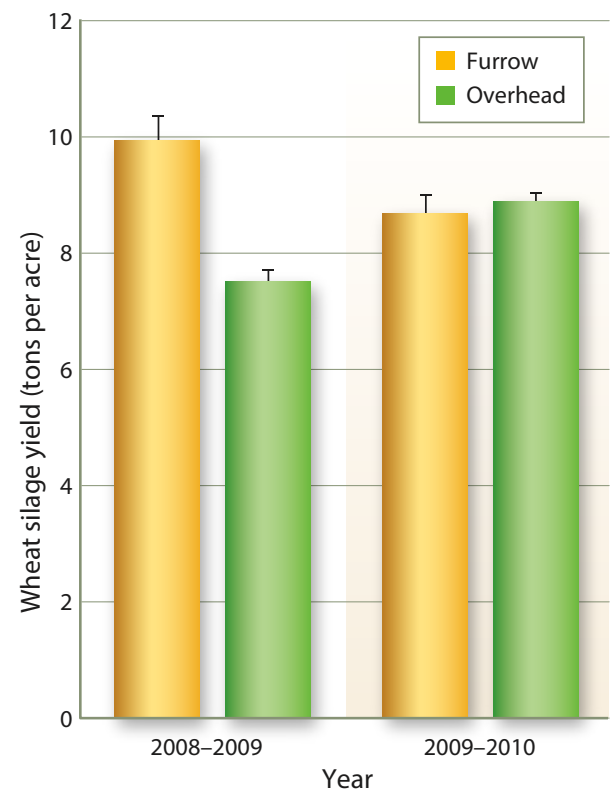

Fig. 1. Wheat silage biomass yield for furrow and overhead irrigation plots, Five Points, 2008-2009 and 2009-2010.
TABLE 2. Comparisons of overhead, furrow (2008-2009, 2009-2010) and SDI (2012-2013) irrigation of wheat, 2008-2013, Five Points

\begin{tabular}{|c|c|c|c|}
\hline & 2008-2009 & 2009-2010 & 2012-2013 \\
\hline \multicolumn{4}{|l|}{ Furrow } \\
\hline Applied water (inches) & 19.1 & 20 & \\
\hline Number of irrigations & 4 & 4 & \\
\hline Yield* & 19,787 a & 17,414 & \\
\hline \multicolumn{4}{|l|}{ SDI } \\
\hline Applied water (inches) & & & 21.7 \\
\hline Number of irrigations & & & 26 \\
\hline Yield* & & & 5,317 \\
\hline \multicolumn{4}{|l|}{ Overhead } \\
\hline Applied water (inches) & 11.8 & 10.6 & 20.8 \\
\hline Number of irrigations & 30 & 18 & 25 \\
\hline Yield* & $15,020 \mathrm{~b}$ & 17,787 NS $\ddagger$ & $5,759 \mathrm{NS}$ \\
\hline $\mathrm{ET}_{\mathrm{o}}$ (inches) & 13.6 & 9.9 & 24.6 \\
\hline Precipitation (inches) & 8.1 & 5.5 & 3.2 \\
\hline Planting date & Dec 11, 2008 & Dec 9, 2009 & Dec 12, 2012 \\
\hline Harvest date & Apr 23, 2009 & Apr 9, 2010 & May 25, 2013 \\
\hline
\end{tabular}

* Ibs per acre for 2008-2009 and 2009-2010 aboveground silage and grain seed yield in 2012-2013.

† Means within a row, for yield, followed by different letters are significantly different according to Fisher's least significant difference test at a significance level of 0.05 .

$\ddagger$ NS $=$ non significant at $P=0.05$. data using small sample sizes to gain insights into growth trends that may not be detected using less frequent sampling. However, frequent sampling has limitations of its own; specifically, it is laborintensive, which in practice can limit the number of replications and thus reduce statistical power.

No yield differences were seen in the 2012-2013 wheat grain crop with similar water application amounts under overhead (5,759 pounds per acre) and SDI (5,317 pounds per acre) systems.

Corn. Irrigations for both the furrow and overhead systems were applied to meet estimated crop ET in each of the three years. As with the wheat crop, increased initial furrow irrigations were needed to establish the corn in the furrow plots, and thus more water was applied in the furrow system than the overhead system (table 3). The overall irrigation

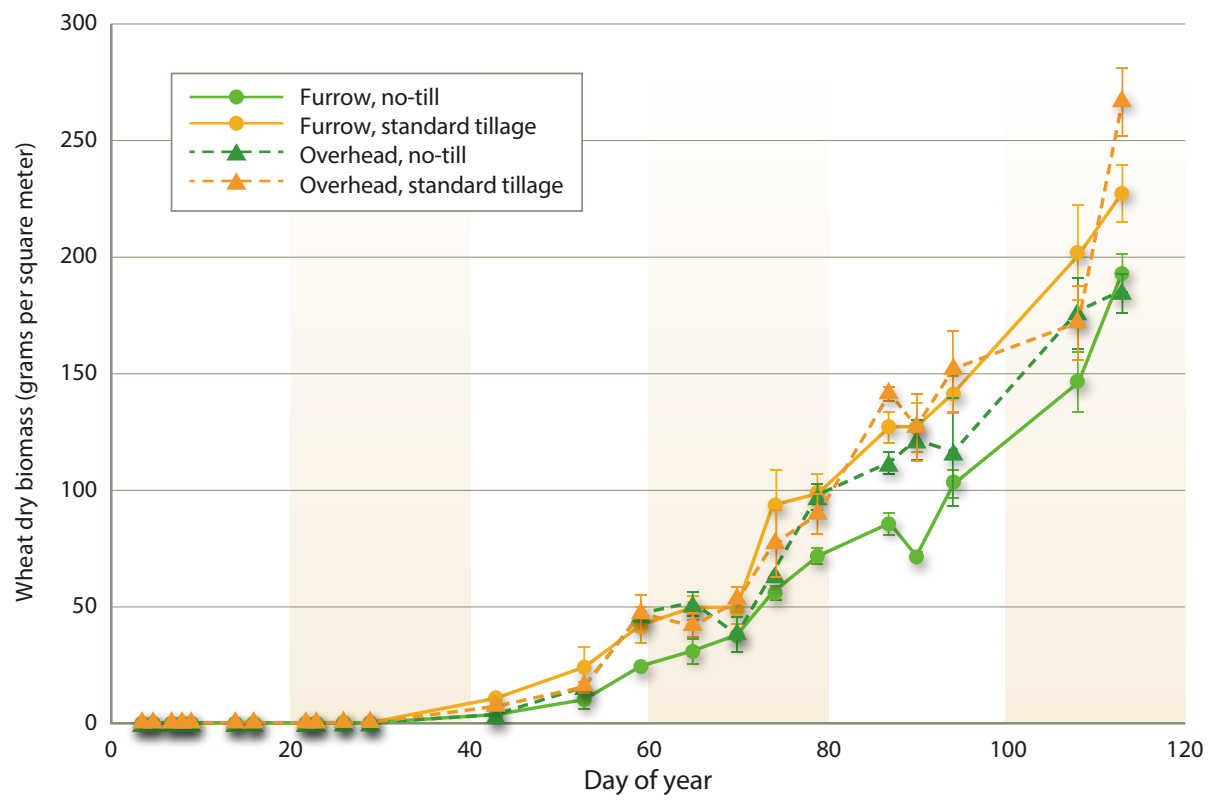

Fig. 2. Wheat silage biomass growth and development for furrow and overhead and standard till and no-till systems in Five Points, 2009-2010. 
amounts were similar to amounts applied in the dairy corn silage fields with furrow systems in the San Joaquin Valley, and the roughly weekly frequency of furrow irrigations matched commercial practices also. A higher frequency of irrigations with smaller application volumes was used for the overhead system.

Over the three years, there were no differences in corn yield due to irrigation system; however, the no-till systems had about $10 \%$ higher $(P=0.001)$ grain yields than the standard plots (fig. 3). This may have resulted from early-season reductions in soil water evaporation in the no-till systems compared to the standard plots due to residues covering the soil surface and there having been no soil-drying tillage disturbance prior to seeding (Klocke et al. 2009; van Donk et al. 2010). As long as adequate crop stands, for yield potential, are achieved at seeding in notill systems, our previous research at Five Points has shown that no-till and residues can reduce soil water evaporation losses by about $13 \%$ compared with bare soil systems, which is the equivalent of about 4 inches of water during a summer crop season (Mitchell et al. 2012). This potential advantage of no-till systems may have been seen in our studies. The no-till comparisons were included in these studies because they are part of our ongoing research efforts to evaluate the performance of systems that couple precision irrigation with low-disturbance tillage.

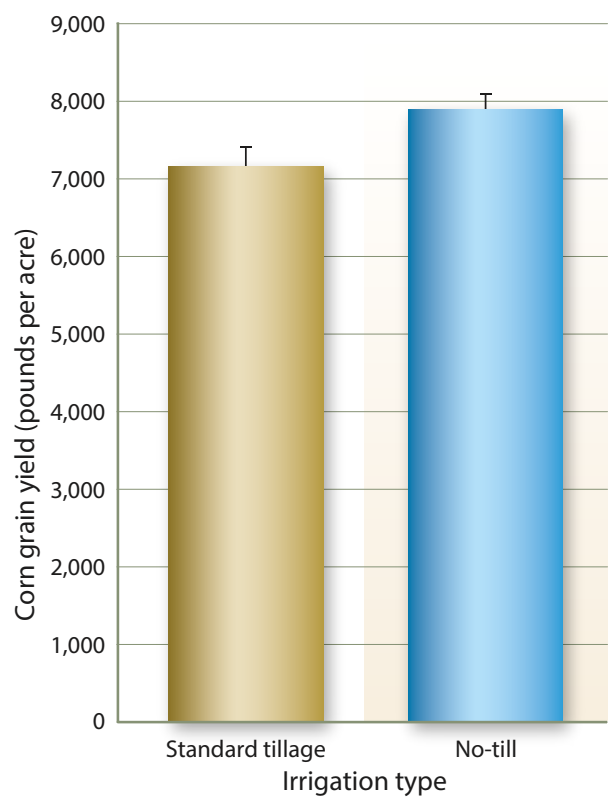

Fig. 3. Corn grain yields for standard tillage and no-tillage systems, Five Points, 2008-2010.
TABLE 3. Comparisons of overhead and furrow irrigation of corn, 2008-2010, Five Points

\begin{tabular}{|c|c|c|c|}
\hline & 2008 & 2009 & 2010 \\
\hline \multicolumn{4}{|l|}{ Furrow } \\
\hline Applied water (inches) & 26.1 & 32.8 & 32.2 \\
\hline Number of irrigations & 12 & 11 & 12 \\
\hline Yield (lbs per acre) & 8,201 & 7,077 & 7,421 \\
\hline \multicolumn{4}{|l|}{ Overhead } \\
\hline Applied water (inches) & 24.3 & 31.6 & 30.3 \\
\hline Number of irrigations & 31 & 56 & 40 \\
\hline Yield (lbs per acre) & 8,378 & 6,259 & 7,191 \\
\hline Planting date & May 8, 2008 & May 6, 2009 & May 14,2010 \\
\hline Harvest date & Sep 29, 2008 & Oct 12, 2009 & Oct 15, 2010 \\
\hline $\mathrm{ET}_{\mathrm{o}}$ (inches) & 39.2 & 41.0 & 40.2 \\
\hline
\end{tabular}

Broccoli. Growth and development of broccoli as determined by a Tetracam ADC wavelength band-separating digital camera (Tetracam, Chatsworth, California) were similar under the overhead and SDI systems (fig. 4) with similar amounts of applied water (table 4). These similar growth patterns resulted in statistically similar broccoli yields $(13,263$ pounds per acre for overhead, and 11,225 pounds per acre for SDI). The applied irrigation water amounts and the yields were on a par with those at commercial farms in this region of the San Joaquin Valley.

Onion, cotton, tomato. In the same fields that were used for the crops discussed above, we also evaluated the performance of the overhead system compared with surface drip in onion crops and SDI in cotton and processing tomato crops. Similar amounts of water were applied to each of these crops in the overhead and drip systems. In 2011 and 2012, we found no differences due to irrigation system in crop growth, development and yield, or quality for cotton (Hollingsworth et al. 2014). For onion, yields were not affected by irrigation in 2011 (39.4 t/ac for drip and $37.8 \mathrm{t} / \mathrm{ac}$ for overhead), but yields were higher in the overhead system in 2013 (28.3 t/ac for drip and $35.1 \mathrm{t} / \mathrm{ac}$ for overhead) (Mitchell et al. 2014).

In evaluations of overhead and SDI systems with tomato crops in 2010 and 2012 (table 5), yields were 48\% higher with the SDI system than the overhead system (Mitchell et al. 2014) (fig. 5). This occurred despite our efforts to vary the overhead irrigation application methods (sprinkler versus bubbler nozzles) and the locations

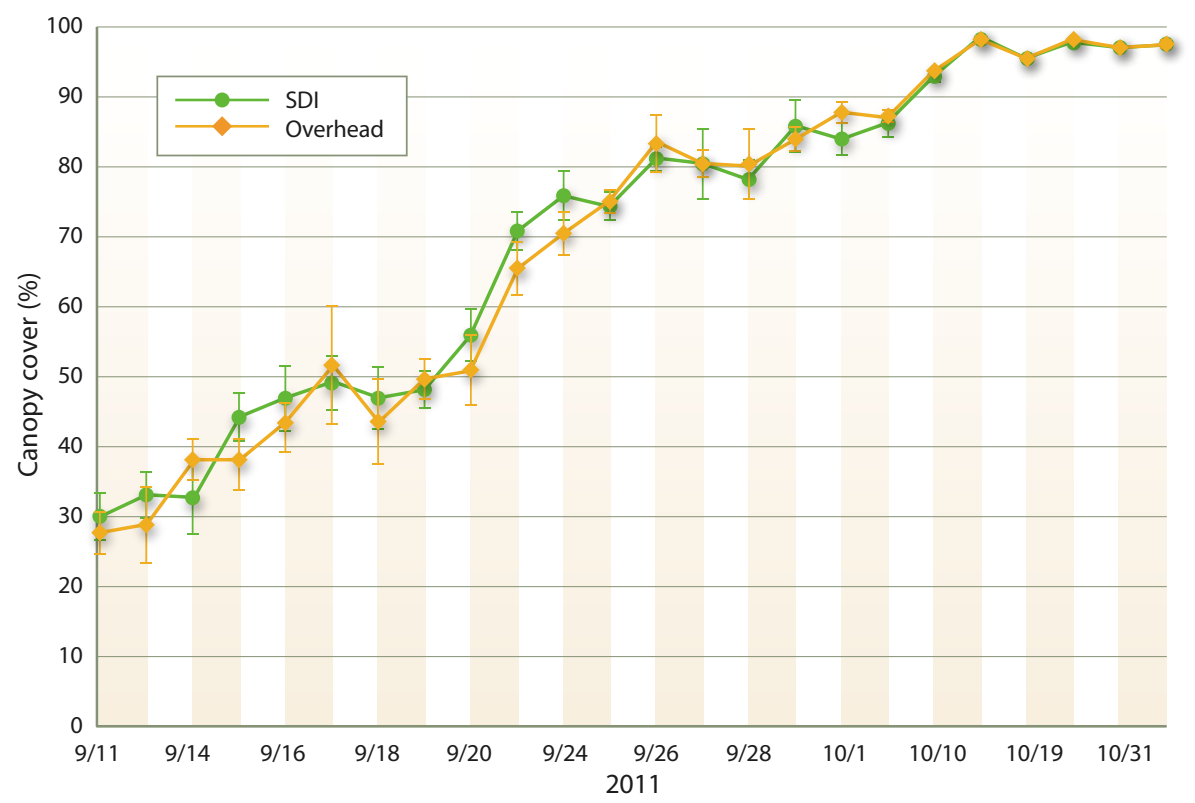

Fig. 4. Broccoli canopy cover (\%) under SDI and overhead irrigation, Five Points, 2011. 


\begin{tabular}{|lc}
\hline $\begin{array}{c}\text { TABLE 4. Comparisons of overhead and SDI } \\
\text { irrigation of broccoli, 2011, Five Points }\end{array}$ \\
\hline \hline SDI & $\mathbf{2 0 1 1}$ \\
\hline Applied water (inches) & 16.9 \\
\hline Number of irrigations & 35 \\
\hline Yield (lbs per acre) & 11,225 \\
\hline Overhead & \\
\hline Applied water (inches) & 15.9 \\
\hline Number of irrigations & 33 \\
\hline Yield (lbs per acre) & 13,263 \\
\hline Et (inches) & 14.9 \\
\hline Precipitation (inches) & 0.9 \\
\hline Planting date & Aug 17,2011 \\
\hline Harvest date & Nov 16,2011 \\
\hline
\end{tabular}

of application devices (directly over plants or over the furrow) to avoid fruit wetting and risks of late-season disease (fig. 6).

The overhead system was used to establish the tomato seedlings in both plots, and then only in the overhead system plots. Bubbler nozzles, which dribble water in a narrow stream, were used in the overhead system plots from transplant establishment through the early vegetative growth phase to apply water directly to the plants and minimize soil water evaporation (fig. 6). The overhead system was then fitted with rotator-type nozzles (Nelson Irrigation, Walla Walla, Washington) with 360-degree random rainfall spray patterns to increase the wetted volume across the beds. At the edges of the split plots, 180-degree center-facing

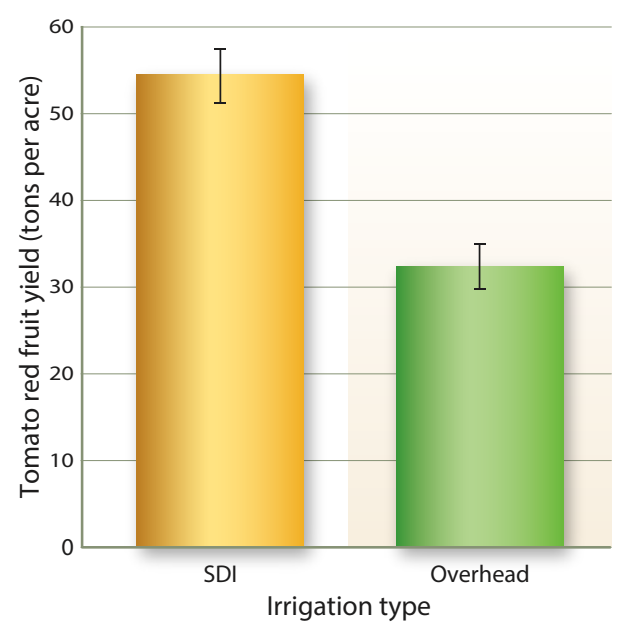

Fig. 5. Average tomato red fruit yields for SDI and overhead systems, Five Points, for 2010 and 2012.

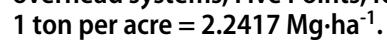

\begin{tabular}{|c|c|c|}
\hline \multicolumn{3}{|c|}{$\begin{array}{l}\text { TABLE 5. Applied water, number of irrigation events, precipitation and } \\
\text { seasonal reference evapotranspiration }\left(\mathrm{ET}_{\mathrm{o}}\right) \text { for comparisons of overhead } \\
\text { and SDI ( } 2010 \text { and } 2012) \text { irrigation of tomato, Five Points }\end{array}$} \\
\hline & 2010 & 2012 \\
\hline \multicolumn{3}{|l|}{ SDI } \\
\hline Applied water (inches) & 23.8 & 33.4 \\
\hline Number of irrigations & 48 & 43 \\
\hline Yield (tons per acre) & $42.2 \mathrm{a}^{*}$ & $66.5 \mathrm{a}$ \\
\hline \multicolumn{3}{|l|}{ Overhead } \\
\hline Applied water (inches) & 22.7 & 33.9 \\
\hline Number of irrigations & 47 & 43 \\
\hline Yield (tons per acre) & $23.9 b$ & $41.1 \mathrm{~b}$ \\
\hline $\mathrm{ET}_{\mathrm{o}}$ (inches) & 25.5 & 26.9 \\
\hline Planting date & April 30, 2010 & April 25, 2012 \\
\hline Harvest date & August 29, 2010 & April 27, 2012 \\
\hline
\end{tabular}
* Means within a row, for yield, followed by different letters are significantly different according to Fisher's least significant difference test at a
significance level of 0.05 . nozzles were used to prevent overspray with the SDI system. Once fruit began to size and mature, the 360-degree nozzles were replaced with bubbler nozzles repositioned in the furrow areas and used until irrigation cutoff before harvest to avoid the potential of rotting fruit due to direct spray (fig. 6).

The significantly lower overhead yields resulted presumably from several factors, the first of which is the higher soil water evaporation losses of the overhead system compared with the SDI system. Overhead irrigation efficiency declines when applied water evaporates from the wetted canopy and from the soil surface before it is used by the crop (Thompson et al. 1997; Tolk et al. 1995). However, total evaporation losses are lowered because crop transpiration is suppressed due to canopy-intercepted water and microclimate modification (Stambouli et al. 2013; Tolk et al. 1995). Field water balance measurements have shown that net evaporation losses from overhead systems range from $5.1 \%$ to $7.1 \%$ of applied water for corn (Tolk et al. 1995) and about 9.8\% during the day and $5.4 \%$ at night for alfalfa (Stambouli et al. 2013).

In our studies, we tried to minimize evaporation losses by using LEPA nozzles early and late season. There were, however, periods during the season in both years when higher levels of evaporation occurred in the overhead system plots than in the SDI system plots, particularly because of the relatively high number of overhead irrigations that were applied.

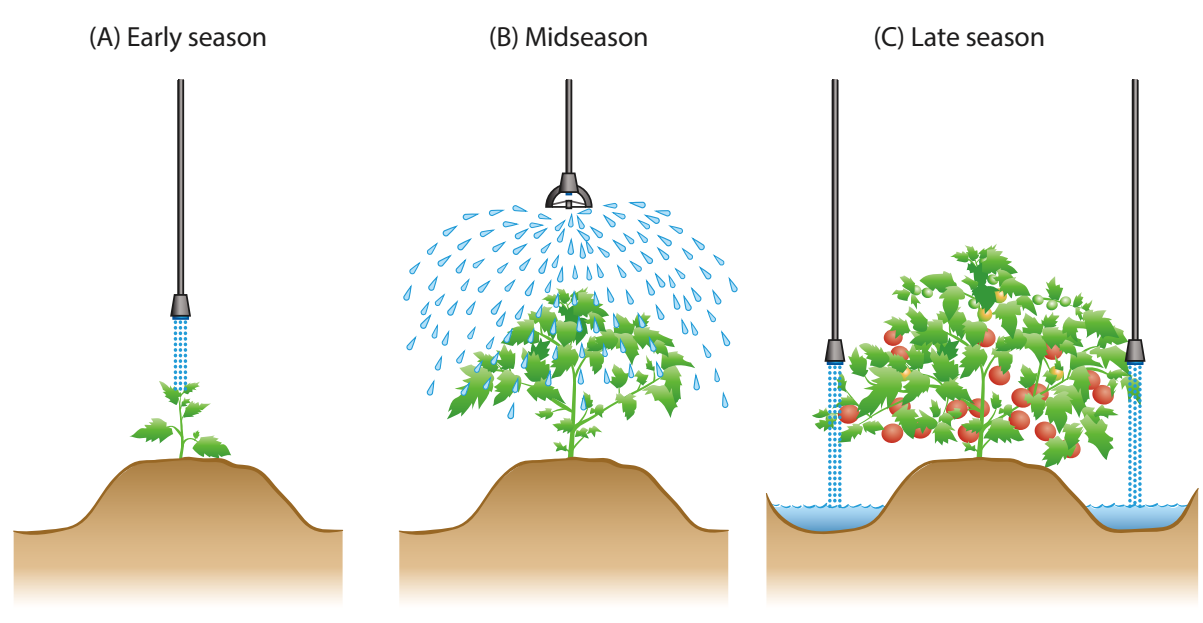

Fig. 6. Overhead irrigation application methods and locations of application devices for (A) early season, (B) midseason and (C) late-season tomato production, Five Points, 2010 and 2012. 
Higher $\mathrm{K}_{\mathrm{c}}$ values and evaporation are expected with higher irrigation frequencies (see sidebar), particularly early in the crop season when more bare soil is exposed (Ventura et al. 2001).

A second factor that may have contributed to the lower yields in the overhead system plots is that no pre-irrigation (root zone soil water replenishment) was done before either of the cropping seasons. Such pre-season, profile-recharging irrigations are commonly used at local commercial farms (Scott Schmidt, farmer, Five Points, personal communication). Having the soil profile full at the beginning of the tomato season might have buffered against the midseason growth reduction and eventual yield losses that were observed in the overhead system plots. We attempted to account for the lack of pre-irrigation by increasing the amount of total water applied to both systems. In the case of the overhead system plots, however, the timing or location of this applied water did not result in increased tomato growth and yield.

A final contributing factor to the lower yields of the overhead system tomato plots was the way in-season liquid fertilizer was applied. With the SDI system, fertilizers were applied directly to the root zone, where acquisition and uptake occur; with the overhead system, fertilizers were applied throughout the entire planting bed area, including the furrow (fig. 6) (Mitchell et al. 2014). The more diffuse application in the overhead system plots may have been a major contributing factor to both the restricted growth and the lower yields there. It could be addressed by a variety of banded or other more precise application methods. Monitoring plant nutrient status may also be a means for improving the performance of the overhead system.

\section{Economics, innovation, research}

Results from our five years of field evaluations generally support the widely recognized value of overhead irrigation technology and indicate that it provides a precision irrigation option that could be of use to a wider segment of California farmers, particularly farmers of most of the crops we studied. Surveys of the numbers of overhead systems that have been recently purchased in California suggest that use of overhead systems is increasing for these crops, and for carrots, where overhead irrigation is now commonly used (Dan Schueler, Senninger Co., personal communication). Overhead irrigation is also now being used commercially in California with alfalfa, sugar beet and potato crops (J. Diener and D. Schueler, personal communication).

Economic considerations are generally the primary factor in the adoption of one irrigation system over another. The yield reductions in the tomato plots that were overhead irrigated would not presently encourage tomato growers to switch from SDI to overhead systems. However, if further research showed that yields with overhead systems could match or nearly match those from SDI, there might be an economic incentive to shift to overhead systems. For example, production costs associated with transitioning from a tomato crop to a sprinkler- or surface drip-irrigated rotation crop such as onion or garlic, which is common in the Central Valley, could be $\$ 130$ to $\$ 430$ per acre lower if the crops were overhead irrigated rather than SDI irrigated.

A few commercial efforts in the Central Valley to use overhead irrigation for tomato production in the 1990s and another more recent attempt in 2009 resulted in unsatisfactory productivity. Additional innovation is needed to improve overhead irrigation of tomatoes, which have a prominent role in many Central Valley annual crop rotations. We are currently working with a team of Central Valley tomato farmers and processors, irrigation company experts and research colleagues to improve overhead irrigation for this crop. A recent effort to use overhead irrigation for processing tomatoes near Walnut Grove, in 2015, was effective in achieving profitable yields (Michael Boparai, personal communication).

Much is known about overhead irrigation management in other U.S. states that could improve the adoption of this technology for diverse crop systems in California. Matching water application rates with infiltration characteristics of the soil is important, to avoid using frequent, light irrigations, as we did, that have greater evaporation losses. Practices that increase infiltration are encouraged; these include gypsum applications, and increasing soil water holding capacity through conservation agriculture (Dumanski et al. 2006; Mitchell, Carter et al. 2015), for example, by reducing soil disturbance (no-till), preserving surface residue and emphasizing biological diversity aboveand belowground. Gypsum applications, however, are not likely to have an impact on sandy, or coarse-textured soils, or under soil conditions that do not have Na-related infiltration problems (K. Bali, personal communication).

Irrigation innovation is an important way for agriculture to become more efficient and sustainable. We believe that

\section{Irrigation frequency and water use efficiency}

ncreasing the volume of applied water at each irrigation event and thereby reducing the number of irrigations during a season reduces evaporation losses and is a means for improving the water use efficiency of the overhead system in soils with sufficient water holding capacity.

The following example illustrates this point. When overhead irrigation occurs over a crop canopy, an inevitable percentage of the applied water captured by the canopy and stored in the uppermost soil surface level is subject to evaporation loss and does not become part of the crop's direct transpiration stream (Philip 1966). The amount of "interception storage" (Fred Lamm, personal communication), which represents a loss of water, varies by crop and canopy architecture; it is about 0.10 of an inch for corn (Thompson et al. 1997). If a 0.5-inch sprinkler irrigation is applied, this 0.10 inch loss is a $20 \%$ loss of the total applied water. If a 1.0-inch irrigation, however, is applied, the loss to evaporation is only $10 \%$.

In a practical sense, best management practice for overhead systems involves applying the largest sprinkler irrigation possible to match the soil's basic infiltration rate and avoid runoff. This will minimize evaporative losses and the risk of growth and yield reductions. It is important to recognize, however, that not only is the soil's infiltration rate important, but so is the ability of the soil to retain applied water. Future research that includes fine-scale measurements of soil water content would help clarify these mechanisms. CA 


\section{We believe that overhead irrigation technology has not gained greater traction in California not because it does not work, but rather because of a lack of concerted attention to the management details that are needed to refine and perfect its adaptability for California cropping systems.}

overhead irrigation technology has not gained greater traction in California not because it does not work, but rather because of a lack of concerted attention to the management details that are needed to refine and perfect its adaptability for California cropping systems. More research is needed, as was done for drip. There is a clear need for research on developing appropriate crop coefficients for overhead systems and for conducting comprehensive economic life-cycle analyses of the various irrigation systems.
Research is also needed on overhead irrigation timing and how to better match water application rates to soil intake characteristics, particularly on fine-textured soils.

Lastly, research into understanding how irrigation system decisions change and new systems are adopted is also important because it will provide information on how to achieve the necessary transformational changes that are challenging agricultural production systems (Awada et al. 2014; Lindwall and Sonntag
2010). Tradition and familiarity with existing common irrigation systems such as surface and SDI are barriers to the adoption of overhead irrigation in California at this time. Given the importance of water shortages and the crop-per-drop considerations that California growers increasingly are facing, more research in this area, and the areas mentioned earlier, would be very important. $C A$

J.P. Mitchell is UC ANR Cooperative Extension (UCCE) Cropping Systems Specialist in the Department of Plant Sciences at UC Davis; A. Shrestha is Professor, California State University, Fresno; J. Hollingsworth is Staff Research Associate, UC ANR Kearney Research and Extension Center; D. Munk is UCCE Advisor, Fresno County; K.J. Hembree is UCCE Advisor, Fresno County; T.A. Turini is UCCE Advisor, Fresno County.

\section{References}

Amosson S, Almas L, Girase JR, et al. 2011. Economics of Irrigation Systems. http://amarillo.tamu.edu/ files/2011/10/Irrigation-Bulletin-FINAL-B6113.pdf. Awada L, Lindwall CW, Sonntag B. 2014. The development and adoption of conservation tillage systems in the Canadian Prairies. ISWCR 2(1):47-65.

Dumanski J, Peiretti R, Benetis J, et al. 2006. The paradigm of conservation tillage. Proc World Assoc Soil and Water Conserv, P1. p 58-64.

Ganzel B. 2006. Center pivots take over. In: Wessels Living History Farm. Farming in the 1950s and 60s. www.livinghistoryfarm.org/farminginthe50s/water_03.html.

Grattan SR, Bowers W, Dong A, et al. 1998. New crop coefficients estimate water use of vegetables, row crops. Calif Agr 52(1):16-21.

Hanson BR, May DM. 2006. New crop coefficients developed for high-yield processing tomatoes. Calif Agr 60(2):95-9.

Hanson BR, Orloff SB. 1996. Rotator nozzles more uniform than spray nozzles on center-pivot sprinklers. Calif Agr 50(1):32-5.

Hanson BR, Schwankl LJ, Fulton AE. 1999. Scheduling irrigations: When and how much water to apply. UC ANR Publication Number 3396.

Hanson BR, Schwankl LJ, Schulbach KF, Pettygrove GS. 1997. A comparison of furrow, surface drip, and subsurface drip irrigation on lettuce yield and applied water. Agric Water Manag 33:139-157. doi:10.1016/S03783774(96)01289-9

Hanson BR, Wallender WW, Ede LL. 1986. Uniformity of continuous-move sprinkler machines. Calif Agr 40(9):10-12.

Harrison K, Perry C. 2013. Evaluating and interpreting application uniformity of center pivot irrigation systems. University of Georgia Cooperative Extension. Circular 911. http://athenaeum.libs.uga.edu/xmlui/bitstream/ handle/10724/12087/C911.pdf? sequence=1.

Hollingsworth J, Mitchell JP, Munk DS, et al. 2014

Subsurface drip and overhead irrigation effects on conservation-tilled cotton in the San Joaquin Valley. J Crop Improvement 28(3):324-44.
Howitt R. 2014. Water, climate change, and California agriculture. Giannini Foundation of Agricultural Economics, UC. Agri Res Econ Update 18(1):13-5.

Hunt, R. 1982. Plant growth curves: Functional approach to plant growth analysis. Edward Arnold, London Klocke NL, Currie RS, Aiken RM. 2009. Soil water evaporation and crop residues. T ASABE 52(1):103-10.

Lindwall CW, Sonntag B. 2010. Landscapes Transformed: The History of Conservation Tillage and Direct Seeding. Saskatoon, Saskatchewan: Knowledge Impact in Society, University of Saskatchewan.

Mitchell JP, Carter LM, Reicosky DC, et al. 2015. A history of tillage in California's Central Valley. Soil Till Res 157:52-64.

Mitchell JP, Klonsky KM, Miyao EM, et al. 2012. Evolution of conservation tillage systems for processing tomato in California's Central Valley. HortTechnology 22(5):1-10.

Mitchell JP, Shrestha A, Klonsky K, et al. 2014. Overhead and drip irrigation system effects on tomato growth and yield in California's Central Valley. HortTechnology 24(6):1-8

Mitchell JP, Shrestha A, Klonsky KM, et al. 2015. Onion growth, yield, and production costs as affected by irrigation system. J Crop Prod 28(6):871-86.

[NASS] National Agricultural Statistics Service, USDA. 2013. Census of Agriculture. Land Irrigated in the Open by Method of Water Distribution: 2013 and 2008. www.agcensus.usda.gov/Publications/2012/ Online_Resources/Farm_and_Ranch_Irrigation_Survey/ fris13_2_028_028.pdf.

O’Brien DM, Rogers DH, Lamm FR, Clark GA. 1998 An economic comparison of subsurface drip and center pivot sprinkler irrigation systems. Appl Eng Ag 14(4):391-98.

Pfeiffer L, Lin CY. 2009. Incentive-based groundwater conservation programs: Perverse consequences. Giannin Foundation of Agricultural Economics, UC. Agri Res Econ Update 12(6):1-4.

Philip JR. 1966. Plant water relations: Some physical aspects. Ann Rev Plant Physio 17:245-68.
Salvucci GD. 1997. Soil and moisture independent estimation of stage-two evaporation from potential evaporation and albedo or surface temperature. Water Resour Res 33(1):111-22.

Smith RB, Oster JD, Phene C. 1991. Subsurface drip produced highest net return in Westlands area study. Calif Agr 45(2):8-10

Splinter WE. 1976. Center-pivot irrigation. Sci Am 234(6):90-9.

Stambouli T, Martinez-Cob A, Maria Faci J, et al. 2013. Sprinkler evaporation losses in alfalfa during solid-set sprinkler irrigation in semiarid areas. Irrig Sci 31:1075-89. Stoddard CS, Klonsky KM, DeMoura RL. 2006. Sample costs to produce sweet potatoes. UC Cooperative Extension. PO-SJ-06.

Takele E, Daugovish O, Vue M. 2013. Costs and Profitability Analysis for Celery Production in the Oxnard Plain, Ventura County, 2012-2013. Ventura, CA. UC Cooperative Extension.

Taylor R, Parker D, Zilberman D. 2014. Contribution of University of California Cooperative Extension to drip irrigation. Giannini Foundation of Agricultural Economics, UC. Agri Res Econ Update 18(2):5-8.

Thompson AL, Martin DL, Norman JM, et al. 1997. Testing of a water loss distribution model for moving sprinkler systems. Trans Amer Soc Agr Eng 40:81-8.

Tolk JA, Howell TA, Steiner JL, et al. 1995. Role of transpiration suppression by evaporation of intercepted water in improving irrigation efficiency. Irr Sci 16:89-95. Tourte L, Smith R. 2010. Sample Production Costs for Wrapped Iceberg Lettuce Sprinkler Irrigated - 40-inch Beds, 2010. UC Cooperative Extension. LT-CC-10.

van Donk SJ, Martin DL, Irmak S, et al. 2010. Crop residue cover effects on evaporation, soil water content, and yield of deficit-irrigated corn in west-central Nebraska. T ASABE 53(6):1787-97.

Ventura F, Faber BA, Bali KM, et al. 2001. Model for estimating evaporation and transpiration from row crops. J Irrig Drainage Eng 127(6):339-45.

Wilson R, Riggs W, Klonsky KM, et al. 2011. Sample Costs to Produce Onions for Dehydrating. UC Cooperative Extension. ON-IR-11. 